\title{
Recycling of cellulases in lignocellulosic hydrolysates using alkaline elution
}

\author{
Ana Cristina Rodrigues ${ }^{\mathrm{a}, 1}$, Alexandre F. Leitão ${ }^{\mathrm{a}, 1}$, Susana Moreira ${ }^{\mathrm{a}}$, Claus Felby ${ }^{\mathrm{b}}$, Miguel Gama ${ }^{\mathrm{a}, *}$ \\ a Departamento Engenharia Biológica, Universidade do Minho, Campus de Gualtar 4710-057 Braga, Portugal \\ ${ }^{\mathrm{b}}$ University of Copenhagen, Faculty of Life Sciences, Rolighedsvej 23, 1958 Frederiksberg, Denmark
}

\section{A R T I C L E I N F O}

\section{Article history:}

Received 31 May 2011

Received in revised form 20 January 2012

Accepted 24 January 2012

Available online 6 February 2012

\section{Keywords:}

Wheat straw

Lignin

Cellulose

Cellulase adsorption/desorption

Enzyme recovery

\begin{abstract}
A B S T R A C T
The recovery of cellulases from lignin, lignocellulosic hydrolysates and cellulose by alkaline washes at pH 9 and 10 was examined. The effect of the $\mathrm{pH}$ on the structural stability of purified Cel7A was analyzed by circular dichroism. Purified Cel7A showed conformational changes at pH 9 and 10 that were reversible at $\mathrm{pH}$ 4.8. Temperature influenced the enzymatic hydrolysis of wheat straw and may be critical for the efficiency of cellulase recycling from wheat straw hydrolysates. Operation at moderate temperatures $\left(37^{\circ} \mathrm{C}\right)$ resulted in a rate of saccharification $19 \%$ higher than that obtained at $50^{\circ} \mathrm{C}$, improving cellulase recycling by $49 \%$. Over $60 \%$ of the enzyme activity on the synthetic substrate 4 -methylumbelliferyl- $\beta$-D-cellobioside (MUC) may be recovered by using a simple alkaline wash. This is thus a promising strategy for enzyme recycling that is simple to implement at industrial scale, economical and effective.
\end{abstract}

(c) 2012 Elsevier Ltd. All rights reserved.

\section{Introduction}

Bioconversion of lignocellulosics to produce bioethanol presents an attractive opportunity for the production of renewable, environmentally friendly biofuels. Although there have been recent advances towards improving the efficiency of the bioconversion process, the cost of hydrolytic enzymes required for the hydrolysis step remains a significant obstacle to the application of this bioconversion technology at commercial scale (Tu et al., 2007a).

Cellulolytic enzymes, such as those obtained from Trichoderma reesei (Palonen et al., 2004; Rosgaard et al., 2007), must be added to the pre-treated lignocellulosic biomass, hydrolyzing and subsequently releasing the soluble fermentable sugars. Herein resides one of the major cost expenditures of the process, accounting for almost $50 \%$ of the cost of the hydrolysis process (Wingren et al., 2003), and so there is a significant need for viable enzyme recycling systems in order to reduce overall ethanol production costs.

The need for pretreatments, such as steam explosion, stems from the recalcitrant nature of lignocellulosic material. Lignin, cellulose and hemicelluloses are intertwined in the cell wall; the steam explosion process breaks down many of the existing bonds between the cell wall components, freeing cellulose so that cellulase adsorption can occur and consequently hydrolysis (Palonen et al., 1999, 2004). Though steam-explosion is cost efficient based on chemical consumption, the severity of the pretreatment affect

\footnotetext{
* Corresponding author. Tel.: +351253604 400; fax: +351253678986.

E-mail address: fmgama@deb.uminho.pt (M. Gama).

1 These authors contributed equally to this work.
}

both the structure of cellulose and lignin (Schevechenko et al., 2001; Eriksson et al., 2002; Lu et al., 2002). Enzymes strongly and irreversible bind lignin, preventing cellulases from reaching cellulose, thus becoming a barrier for efficient hydrolysis (Palonen et al., 1999; Ramos et al., 1992). Deshpande and Eriksson (1984) showed that lignin does not inactivate these cellulolytic enzymes, but rather a large amount of enzymes, up to $40 \%$, bind unspecifically to lignin after complete hydrolysis of wheat straw (Palonen et al., 2004).

Several methods have been proposed to minimize enzyme adsorption to lignin, such as introducing surfactants such as Tween 80 (Tu et al., 2007b), proteins like BSA (Yang and Wayman, 2006) or encapsulation of the cellulases (Li et al., 2008). Other methods have attempted to remove or reduce the amount of lignin in the lignocellulosic material by dissolving it with Organosolv (Zhao et al., 2009), DMSO (Fasching et al., 2008), COSLIF (Rollin et al., 2011) or the use of ionic liquids (Tan et al., 2009).

However, due to the cost of some of these pretreatments or surfactants, their potential for actual application is low. Given the high thermal and pH stability of cellulolytic enzymes (Bajaj et al., 2009) and considering that up to $88 \%$ of enzymatic activity is retained after desorption from lignin (Tu et al., 2007a), it appears that a cost-efficient method of enzyme recycling from the leftover lignin biomass is not only viable but important in reducing production costs.

Some authors have proposed that enzymes can be recovered by re-adsorption onto fresh substrates (Lee et al., 1995; Ramos et al., 1992). However, this strategy would result in an increased build up of lignin rich residues that would ultimately have an adverse effect on the hydrolytic ability of the recovered enzyme, in subsequent 
hydrolysis of fresh substrates (Lee et al., 1995; Tu et al., 2007a, 2007b; Qi et al., 2011). Other authors reported that alkaline media (for example sodium hydroxide solutions with $\mathrm{pH} 9$ and 10) were very effective desorption agents (Otter et al., 1984; Zhu et al., 2009). A protein mass balance performed by these authors showed a recovery of up to $45 \%$ (Otter et al., 1984) or more than $90 \%$ of cellulases (Zhu et al., 2009). However, these authors did not report on the activity of the recovered protein.

In the present study, soluble low molecular mass fluorogenic specific substrates were used for determining the activities of adsorbed cellulases. Cel7A (or CBH I, cellobiohydrolase I from $T$. reesei) retained its activity even when adsorbed onto lignin; furthermore, a mild switch in $\mathrm{pH}$ from 4.8 to 9 is sufficient to induce reversible conformational and structural changes, which may explain the desorption of a significant amount of the enzyme without losing MUC activity when the $\mathrm{pH}$ is reset. Additionally, with an alkaline wash at pH 9 or 10 it was possible to recover a large portion of enzymatic activity from extensively hydrolyzed wheat straw.

\section{Methods}

\subsection{Lignin isolation}

Lignin was obtained by extensive hydrolysis of steam pretreated wheat straw with a mixture of Celluclast 1.5 FG L and Novozym 188 (both from Novozymes A/S, Basgsværd, Denmark) in a $5: 1$ weight ratio - with an activity of $85 \mathrm{FPU} / \mathrm{ml}$ - and was provided by the Inbicon pilot plant in Skorbok, Fredericia, Denmark (Laresen et al., 2008), in the framework of the FP7 project KACELLE. The resulting freeze dried material was further treated with $2 \%(\mathrm{v} / \mathrm{v})$ alcalase in $50 \mathrm{mM}$ Tris- $\mathrm{HCl}$ (Sigma-Aldrich, 99\%) pH 7 buffer for $24 \mathrm{~h}$, washed and alkaline treated at $\mathrm{pH} 10$ for $2 \mathrm{~h}$ followed by $\mathrm{pH}$ change to 2 by addition of $18 \% \mathrm{HCl}$ (Sigma-Aldrich) in order to precipitate dissolved lignin. Lignin was washed and placed in $50 \mathrm{mM}$ sodium acetate (NaAc) (Sigma-Aldrich) buffer $\mathrm{pH}$ 4.8. The resulting material had minimal protein content and assumed as a pure lignin fraction.

\subsection{Cel7A purification}

An enriched preparation of Cel7A was obtained in a one-step Fast Protein Liquid Ion Exchange Chromatography process using a Mono Q HR 5/5 ion exchange column from Amersham Biosciences (GE Healthcare). The enzyme mixture of Celluclast 1.5 FG L and Novozym 188 (both from Novozymes A/S, Basgsvaerd, Denmark provided by the Inbicon pilot plant (Denmark) in the framework of the FP7 project KACELLE) was buffer exchanged into $50 \mathrm{mM}$ Tris- $\mathrm{HCl} \mathrm{pH} 8$ buffer and injected into the aforementioned column at a flow rate of $0.5 \mathrm{ml} / \mathrm{min}$. The elution buffer was a $50 \mathrm{mM}$ solution of Tris- $\mathrm{HCl}$ with $1 \mathrm{M} \mathrm{NaCl}$ (Sigma-Aldrich) at $\mathrm{pH}$ 8. The fraction corresponding to Cel7A was found to be substantially pure, and buffer exchanged using an ultrafiltration device (Amicon, $10 \mathrm{kDa}$ polysulfone membrane, Omega $25 \mathrm{~mm}$ ) to $50 \mathrm{mM} \mathrm{NaAc}$ buffer at $\mathrm{pH}$ 4.8. Purity was confirmed by SDS-PAGE analysis (data not shown). Enzyme concentration of Cel7A stock was assessed using the Bradford protein (Bio-Rad) assay and stocks were stored at $-4^{\circ} \mathrm{C}$.

\subsection{Activity of lignin-bound Cel7A}

Cel7A concentrations of $0.5 ; 0.3$ and $0.156 \mathrm{mg} / \mathrm{ml}$ were added to a $2 \%(\mathrm{w} / \mathrm{v})$ lignin suspension in $50 \mathrm{mM}$ NaAc buffer at $\mathrm{pH} 4.8$ and placed on a turning wheel at $20 \mathrm{rpm}$ (Rotator SB3-Stuart) at room temperature. Samples were taken at 2, 24, 48, 72 and 168 h, centri- fuged at $4480 \mathrm{~g}$ for $10 \mathrm{~min}$ (microcentrifuge Sigma, modell 113), washed with one volume of supernatant, and enzymatic activity of the suspension, supernatant and solid fraction was assayed using 4-methylumbelliferyl- $\beta$-D-cellobioside as substrate (MUC assay; Sigma-Aldrich). For the purpose of the MUC assay these samples were diluted 1:100 so as to fall inside the calibration curve.

All experiments were performed in duplicate and were repeated twice, and mean values and standard deviations are presented.

\subsection{Assays for enzyme activity - MUC assay}

Cel7A activity was measured by fluorescence spectroscopy with a Biotech Synergy HT Elisa plate reader, using 4-methylumbelliferyl- $\beta$-D-cellobioside (MUC) as a substrate (Sigma-Aldrich). Upon hydrolysis of MUC by Cel7A, free 4-methylumbelliferone (4MU, Sigma-Aldrich) caused a shift in the fluorescence spectra (excitation maximum/fluorescence maximum). Enzyme activity was measured by the fluorescence of 4-methylumbelliferone with an excitation and emission wavelengths of 360 and $460 \mathrm{~nm}$ respectively. A $1 \mathrm{mM}$ stock solution of 4-methylumbelliferone was diluted from $0.0001 \mathrm{mM}$ to $0.01 \mathrm{mM}$ and used to prepare a calibration curve by plotting 4-methylumbelliferone concentration $(\mathrm{mM})$ versus relative fluorescence units (RFU) and to determine the least squares regression equation for the line generated by the standard 4MU samples. To quantitatively assay the samples for Cel7A activity, a solution of $1 \mathrm{mM} 4$-methylumbelliferyl- $\beta$-D-cellobioside was prepared in $0.1 \mathrm{M}$ sodium acetate buffer $\mathrm{pH} 4.8$. A test sample $(37.5 \mu \mathrm{l})$ was added to the reaction mixture (300 $\mu \mathrm{l} \mathrm{MUC)}$ and incubated at $50{ }^{\circ} \mathrm{C}$ for $15 \mathrm{~min}, 375 \mu \mathrm{l}$ of $1 \mathrm{M} \mathrm{Na}_{2} \mathrm{CO}_{3}$ buffer was added to the mixture to stop the reaction and measured on a black bottom 96-well UV fluorescence microplate. The amount of MUC hydrolyzed was determined by inserting the relative fluorescence (RFU) into the linear equation obtained using MU standard solutions ( $R F U=151,254 \times[4-M U$ concentration $]+31.102$, $\left.R^{2}=1.00\right)$. Whenever the sample readings fell outside the standard curve, the enzyme sample was diluted and the experiment repeated. All assays were performed in triplicate. The amounts of MUC hydrolyzed (mM) were converted to enzyme activity units, where enzyme activity units $(\mathrm{U} / \mathrm{L})$ is defined as the amount of enzyme that catalyzes the transformation of one micromole of substrate per minute under specified conditions.

The above described methodology was further validated. The correlation between the enzyme concentration and the release of 4-methylumbelliferone under the conditions of the MUC assay was analyzed. For this purpose, various dilutions of enzyme were prepared. MUC assays were performed for each enzyme concentration, and it was found that with increasing concentration of enzyme the release of 4-methylumbelliferone increased, in a linear way $(\mathrm{RFU}=481,811 \times$ [enzyme concentration $]+349.78$; $R^{2}=0.99$ ).

\subsection{Activity on filter paper fibers}

Activity on filter paper fibers was used to verify whether the enzyme recovered after the alkaline treatment (after different temperatures hydrolysis) remained active on insoluble and crystalline cellulose, and to compare its activity with the initial one at an identical dilution.

The filter paper fibers assay was performed according to the National Renewable Energy Laboratory protocol LAP-006 (Adney and Baker, 1996). Whatman No. 1 Filter Paper was cut into $6 \times 1 \mathrm{~cm}$ strips (weighing $50 \mathrm{mg}$ ). The strips where placed in $1 \mathrm{ml}$ of $0.1 \mathrm{M}$ $\mathrm{NaAc} \mathrm{pH} 4.8$ buffer and equilibrated at $50^{\circ} \mathrm{C}$. Afterwards, $0.5 \mathrm{ml}$ of enzyme samples were added and incubated for $1 \mathrm{~h}$. After $1 \mathrm{~h}$, each tube was taken and used for quantification of total reducing sugars by the DNS assay, using glucose as standard. Samples of 
$100 \mu \mathrm{l}$ from each incubated tube were added to $100 \mu \mathrm{l}$ of DNS reagent and placed in boiling water for $5 \mathrm{~min}$. One $\mathrm{ml}$ of distilled water was added and $200 \mu \mathrm{l}$ pipetted into a well of a 96-well microplate in triplicate and absorbance measured at $540 \mathrm{~nm}$. The results of this assay are presented as the concentration of sugars hydrolyzed after $1 \mathrm{~h}$ incubation and are expressed in $\mathrm{mg} / \mathrm{ml}$ of total reducing sugars using glucose as standard.

All experiments were performed in triplicate and were repeated twice, and the mean values and standard deviations are presented.

\subsection{Enzyme desorption assay}

Cel7A was added to a $2 \%(\mathrm{w} / \mathrm{v})$ lignin suspension or $2 \%$ cellulose CF11 (Whatman) to a final concentration of $0.3 \mathrm{mg} / \mathrm{ml}$ and incubated at room. The samples (total volume of $10 \mathrm{ml}$ in Falcon tubes were placed on a turning wheel rotating at $20 \mathrm{rpm}$ ). Time points for sampling were $24,48,72$ and $168 \mathrm{~h}$ for lignin. With cellulose CF11 (Whatman) only two time points (24 and $48 \mathrm{~h}$ ) were sampled.

The concentration of hydrolyzed sugars in the assays with cellulose CF11 (Whatman) was determined at 2, 6, 12, 24, 29, 36 and $48 \mathrm{~h}$ by the DNS assay.

At each time point, a sample of the suspension was taken and centrifuged at $4480 \mathrm{~g}$ for $10 \mathrm{~min}$ (microcentrifuge Sigma, modell 113), the supernatant removed, and the solid fraction was subjected to an alkaline wash treatment.

All experiments were performed in triplicate and were repeated twice, and the mean values and standard deviations are presented

\subsubsection{Alkaline wash treatment}

The solid fraction was re-suspended in $50 \mathrm{mM}$ Tris- $\mathrm{HCl}$ buffer at $\mathrm{pH} 9$ or 10 and left for $2 \mathrm{~h}$ at room temperature (on a turning wheel at $40 \mathrm{rpm}$, Rotator SB 3 - Stuart). The suspension was centrifuged at $4480 \mathrm{~g}$ for $10 \mathrm{~min}$ (microcentrifuge Sigma, modell 113) to separate the supernatant from the solid fraction. The samples, both supernatant and solid fraction, were diluted in $0.1 \mathrm{M} \mathrm{NaAc}$ buffer at $\mathrm{pH} 4.8$ and left at room temperature for $1 \mathrm{~h}$, then assayed by MUC assay to determine enzymatic activity.

\subsection{Enzymatic hydrolysis of steam pretreated wheat straw and enzyme recovery}

Wheat straw was pretreated by steam pretreatment in the Inbicon pilot plant and stored at $4{ }^{\circ} \mathrm{C}$. Unless otherwise stated, all enzymatic hydrolysis experiments were performed in $10 \mathrm{ml}$ of $0.1 \mathrm{M}$ $\mathrm{NaAc}$ buffer at pH 4.8 with a solid suspension of $5 \%(\mathrm{w} / \mathrm{v})$ total dry matter. The reaction medium was incubated at 30, 37, 40, 45, or $50^{\circ} \mathrm{C}$, using a turning wheel at $20 \mathrm{rpm}$ (Rotator SB 3 - Stuart). At 24 and $48 \mathrm{~h}$ of hydrolysis each tube was centrifuged at $3219 \mathrm{~g}$ for $1 \mathrm{~h}$ (Heraeus Megafuge $1.0 \mathrm{R}$ ); the supernatant was removed and fresh buffer and a cellulase loading of $2.1 \mathrm{FPU} / \mathrm{ml}$ (Celluclast and Novozym 188 mixture) was added. From this moment on, at each $24 \mathrm{~h}$ interval, up to $168 \mathrm{~h}$, the tubes were centrifuged at $3219 \mathrm{~g}$ for $1 \mathrm{~h}$ (Heraeus Megafuge $1.0 \mathrm{R}$ ); The supernatant was removed and concentrated ten-fold, using an ultrafiltration device (Amicon, $10 \mathrm{kDa}$ polysulfone membrane, Omega $25 \mathrm{~mm}$ ) and "washed" with $5 \mathrm{ml}$ of fresh $0.1 \mathrm{M} \mathrm{NaAc}, \mathrm{pH} 4.8$ buffer to remove any sugars and other low molecular weight compounds that may interfere with enzyme activity. The retentate was collected and added to the substrate and fresh buffer to carry out the subsequent rounds of hydrolysis. The process was repeated every $24 \mathrm{~h}$ after the initial $48 \mathrm{~h}$ up to the final $168 \mathrm{~h}$ point.

The conversion of steam-pretreated wheat straw at different temperatures was estimated by determining the reducing sugar content of the supernatant after enzymatic hydrolysis, using the 3,5-dinitrosalicylic acid reagent (DNS) method and glucose as the standard. The conversion of lignocellulosic material was determined as follows:

$$
\text { Conversion }=\frac{\mathrm{mg} \text { reducing sugar produced } \times 0.8875}{\mathrm{mg} \text { of dry straw }}
$$

where 0.8875 is the factor considering the mass molecular ratio between anhydroglucose contained in cellulose and free glucose.Then

total conversion (time) $=\sum_{24 h}^{168 h}$ conversion

In the thermal stability assay, a test tube with $2.1 \mathrm{FPU} / \mathrm{ml}$ (Celluclast and Novozym 188 mixture) in $10 \mathrm{ml}$ of $0.1 \mathrm{M}$ NaAc buffer at $\mathrm{pH} 4.8$, without lignocellulosics, was processed in parallel and the MUC activity was measured every $24 \mathrm{~h}$.

After a week of hydrolysis the solid fraction was alkaline washed with $50 \mathrm{mM}$ Tris- $\mathrm{HCl}$ buffer at pH 9 and 10, as described in Section 2.6.1, for $2 \mathrm{~h}$. The supernatant recovered and activity measured by both the MUC and the filter paper fibers assay.

All experiments were performed in duplicate and were repeated twice, and mean values and standard deviations are presented.

\subsection{Enzyme pH stability}

Intrinsic tryptophan fluorescence (ITF) was used to determine structural changes of Cel7 A at $\mathrm{pH} 4.8,9$ and 10. Cel7A samples were diluted, to a final concentration of $0.5 \mathrm{mg} / \mathrm{ml}$ at the desired pH's, in $50 \mathrm{mM} \mathrm{NaAc}$ buffer $\mathrm{pH} 4.8$ and $50 \mathrm{mM}$ Tris- $\mathrm{HCl}$ buffer $\mathrm{pH} 9$ and 10, for $2 \mathrm{~h}$ before ITF spectrum measurements. The diluted samples, 1:5 in respective buffers, were analyzed with an excitation wavelengths of $270 \mathrm{~nm}$ and recorded over a spectrum of emission wavelengths from 290 to $450 \mathrm{~nm}$. The samples at $\mathrm{pH}$ 9 and 10 were diluted (1:5) in $50 \mathrm{mM} \mathrm{NaAc}$ buffer at $\mathrm{pH} 4.8$ and measured again, under the same conditions, in order to determine if the structural changes were reversible. Additionally, circular dichroism (CD) was carried out at the University of Coimbra. Spectra were obtained on an Olis DSM CD spectrometer. CD spectra were obtained at $20^{\circ} \mathrm{C}$ over a range between 260 and $190 \mathrm{~nm}$. This test was performed in the absence of lignin.

\subsection{Statistical analysis}

All statistical analyses were performed using analysis of variance One-Way ANOVA.

\section{Results and discussion}

\subsection{Activity of lignin-bound Cel7A}

Cel7 A is the most abundant protein among the cellulases secreted by $T$. reesei (Rosgaard et al., 2007). The Cel7A interaction with lignin was shown by Palonen et al. (2004) to affect the binding domain of the enzyme, while not altering the structure of the catalytic domain.

This seems to be supported by findings that when cellulases previously adsorbed to lignin are recovered by re-adsorption onto fresh substrate, there is no loss of activity, at least during the initial rounds of hydrolysis (Tu et al., 2007a,b). The questions that arises, is whether lignin-bound Cel7A's activity is diminished. The MUC assay was used since 4-methlyumbelliferyl- $\beta$-D-cellobioside is small enough so that it can be hydrolyzed while Cel7A remains adsorbed to lignin.

In this week-long experiment Cel7A was left at room temperature in a $2 \%(\mathrm{w} / \mathrm{v})$ suspension of purified lignin so that the enzyme could adsorb onto the lignin exclusively. In accordance with other authors (Deshpande and Eriksson, 1984; Palonen et al. 2004), it 
could be shown for different enzyme loadings that the presence of lignin does not influence MUC activity of Cel7A (Fig. 1) since no statistically significant differences $(p>0.05)$ were detected between the results for Cel7A in the presence and absence of lignin (Cel7A+L and Cel7A).

\subsection{Enzyme desorption assay}

It has been shown that by addition of fresh lignocellulosic substrate it is possible to recover and recycle cellulases and that addition of surfactants to the reaction solution can increase the total amount of recoverable enzyme (Tu et al., 2007b; Yang and Wayman, 2006). This kind of recycling strategy intends to minimize the amount of cellulases that adsorbs irreversibly to lignin and consequently constitute the portion of enzyme that is ultimately lost. Possible recovery of these cellulases would significantly contribute to lowering production costs of second generation bioethanol production.

The results presented in Fig. 1 Cel7A adsorbed onto lignin retains activity. Zhu et al. (2009) and Otter et al. (1984) showed that it is possible through alkaline wash to recover a large portion of adsorbed cellulases but it remains to be shown if the enzymes remain active after exposure to alkaline $\mathrm{pH}$.

Through intrinsic tryptophan fluorescence (ITF) and circular dichroism (CD) we tested the conformational stability of Cel7A in alkaline medium and its recovery after resetting the $\mathrm{pH}$ to our storage conditions of $\mathrm{pH} 4.8$ (Fig. 2A-C). ITF measures conformational changes by taking advantage of tryptophan's sensitivity to its surrounding environment. As can be seen in the ITF spectra, when $\mathrm{pH}$ was altered from pH 4.8 to $\mathrm{pH} 9$ or 10 (Fig. 2A), significant conformational changes occured, that were reversed at pH 4.8 (Fig. 2B). This finding is supported by $\mathrm{CD}$ results which showed that at $\mathrm{pH}$ 4.8 Cel7A has a secondary structure consisting of roughly the same amount of $\alpha$-helixes and $\beta$-sheets (Fig. 2C). This structure is partially lost at $\mathrm{pH} 10$, but is regained at $\mathrm{pH} 6$. According to results obtained using the MUC assay, the $\mathrm{pH}$ switch does not induce any loss of MUC activity of Cel7A (as shown ahead, please see Figs. 3 and 5).

Since pH 9 did not appear to affect the structural integrity of the enzyme, desorption assays into pure lignin were conducted at this $\mathrm{pH}$. Results show that it was possible to recover a significant amount of previously adsorbed enzyme Cel7A by altering the $\mathrm{pH}$
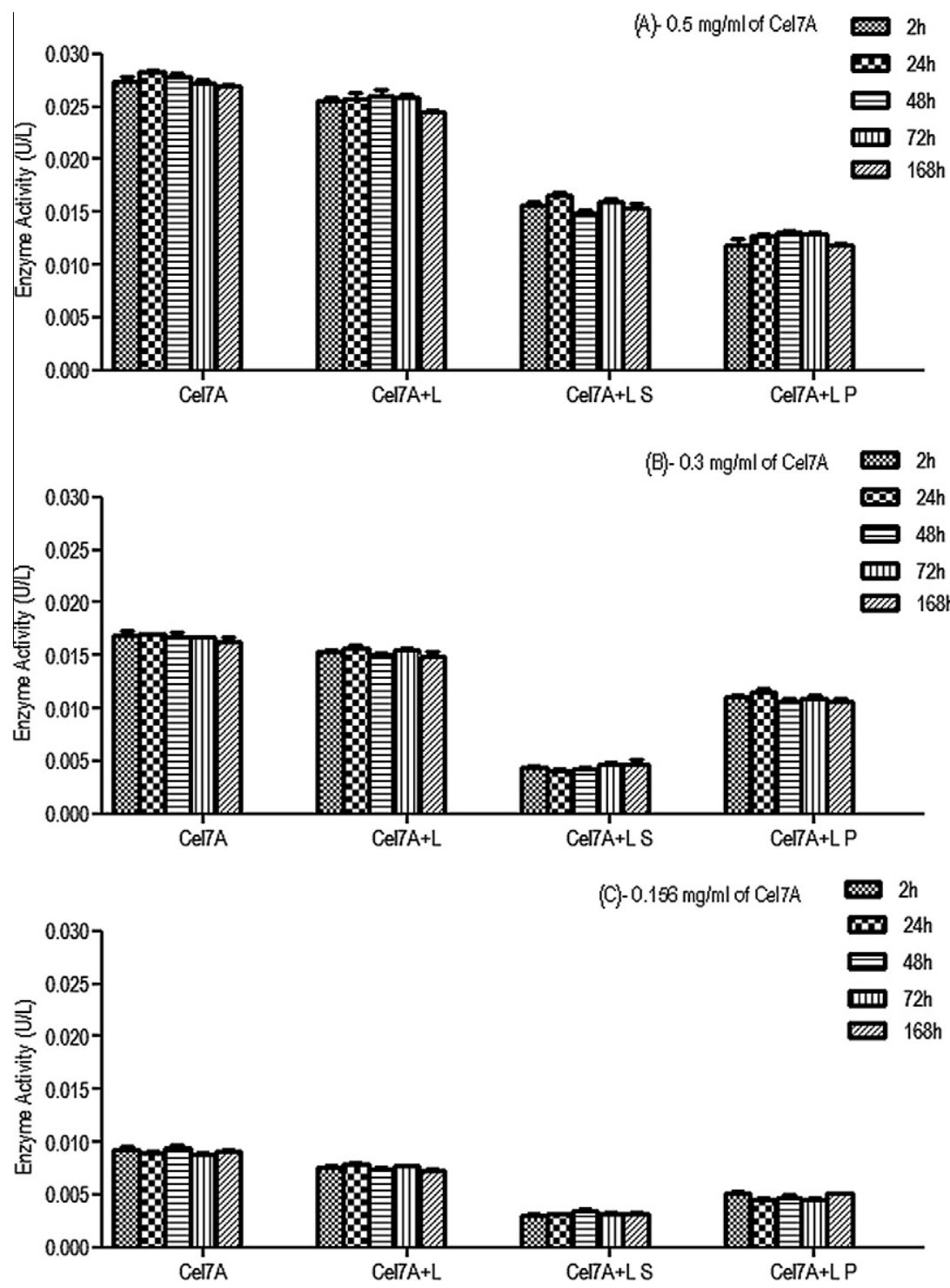

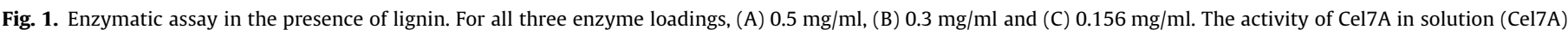

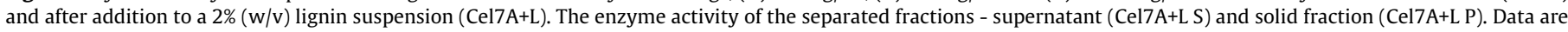
expressed as the mean $\pm \mathrm{SD}$ (error bars) of two independent experiments performed in duplicate. 

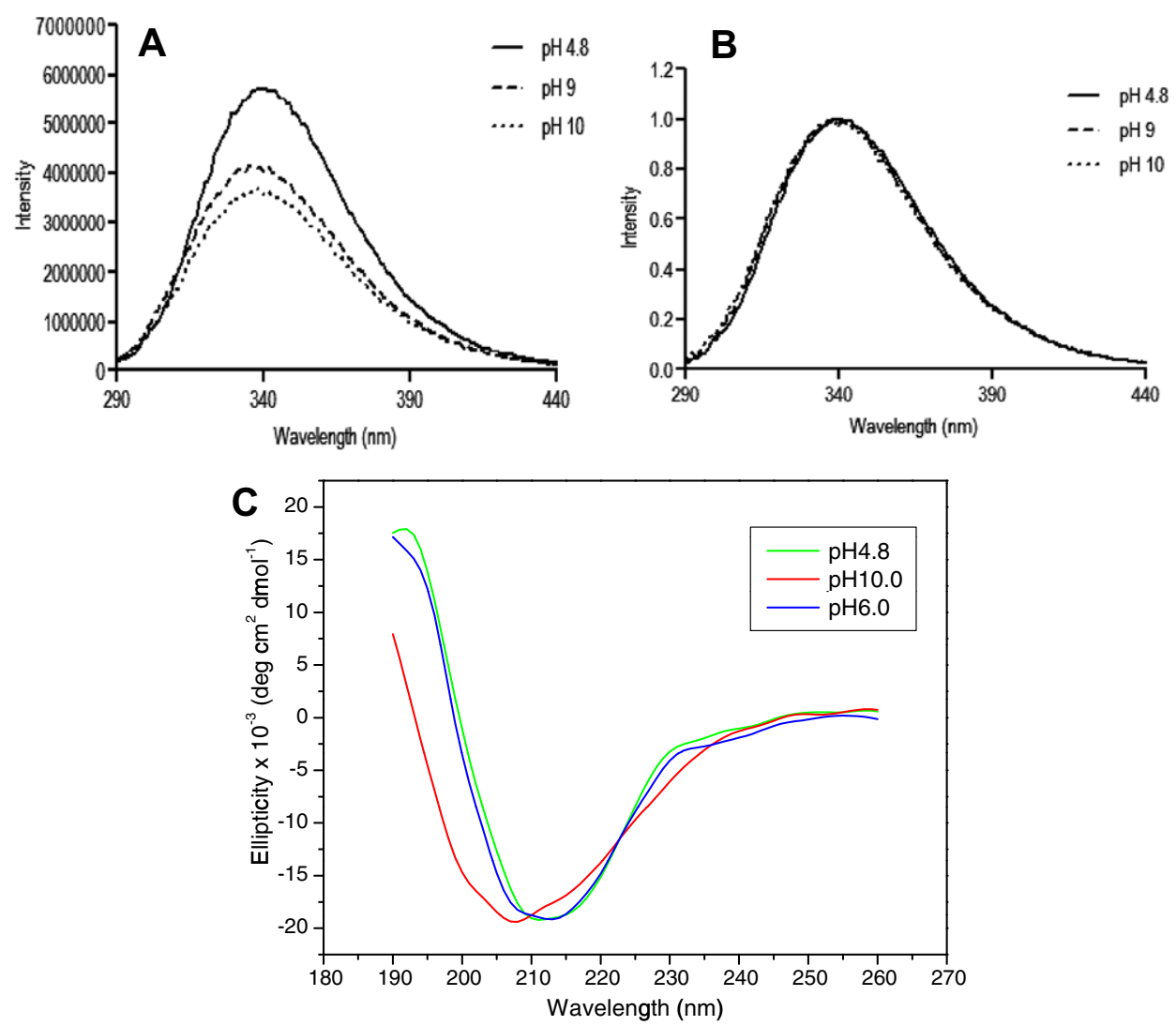

Fig. 2. (A) Intrinsic tryptophan fluorescence emission spectra of Cel7 A at $\mathrm{pH} 4.8,9$ and 10. (B) Intrinsic tryptophan fluorescence emission spectra of Cel7A after resetting pH to 4.8. Progression the spectrum for $\mathrm{pH} 4.8$ (-), which serves as a positive control, $\mathrm{pH} 9(--\cdot)$ and $10(\cdots)$ ). (C) Circular dichroism spectra of Cel7A at different pHs. At pH 4.8 (green) and 6 (blue) and $\mathrm{pH} 10$ (red). (For interpretation of the references to color in this figure legend, the reader is referred to the web version of this article)

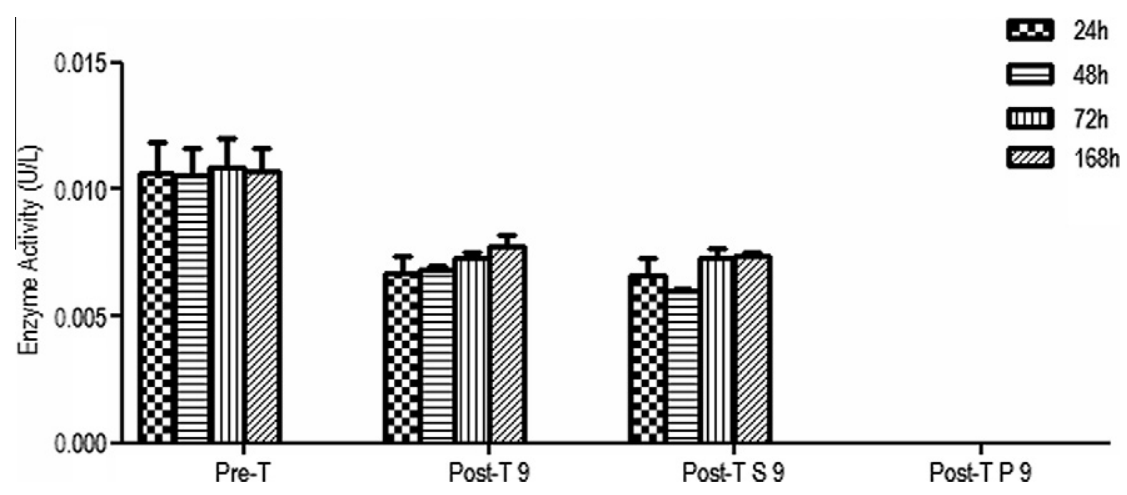

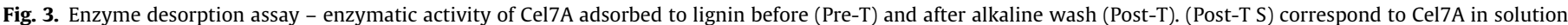

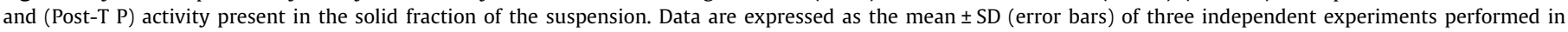
duplicate.

(Fig. 3). The amount of enzyme recovered was lowered due to washing of the solid fraction with buffer before the $\mathrm{pH}$ change (Fig. 3 columns Post-T 9).

The results also showed that the time the cellulase was in contact with lignin did not influence the recoverable amount of enzyme since no statistically significant differences $(p>0.05)$ were detected between the recovery of enzyme exposed to lignin for 24 or 168 h (Fig 3 Post-T S 9).

\subsection{Enzymatic hydrolysis of steam pretreated wheat straw and enzyme recovery}

Since alkaline wash at pH 9 seems to be a promising method to promote enzyme desorption and subsequent recovery of active and viable Cel7A from a lignin substrate, this method was applied to an enzyme mixture, Celluclast 1.5 FG L. Wheat straw pretreated by steam pretreatment was used as a substrate for hydrolysis with Celluclast 1.5 FG L and Novozym 188, to determine if it was possible to recover enzyme after an extensive hydrolysis of a substrate used in second generation bioethanol production (Petersen et al., 2009).

Fig. 4A shows the temperature dependence of reducing sugars production from wheat straw. As expected, the rate of reducing sugars production dropped over the time course of the experiment (Fig. 4A). The thermostability of Cel7A was analyzed by MUC assay, and the enzyme did not lose any MUC activity at 30,37 and $40^{\circ} \mathrm{C}$ Fig. 4B. However, MUC activity significantly decreased above $45^{\circ} \mathrm{C}$. Only $37.5 \%$ of the original activity remained at $50{ }^{\circ} \mathrm{C}$, and $89.7 \%$ at 

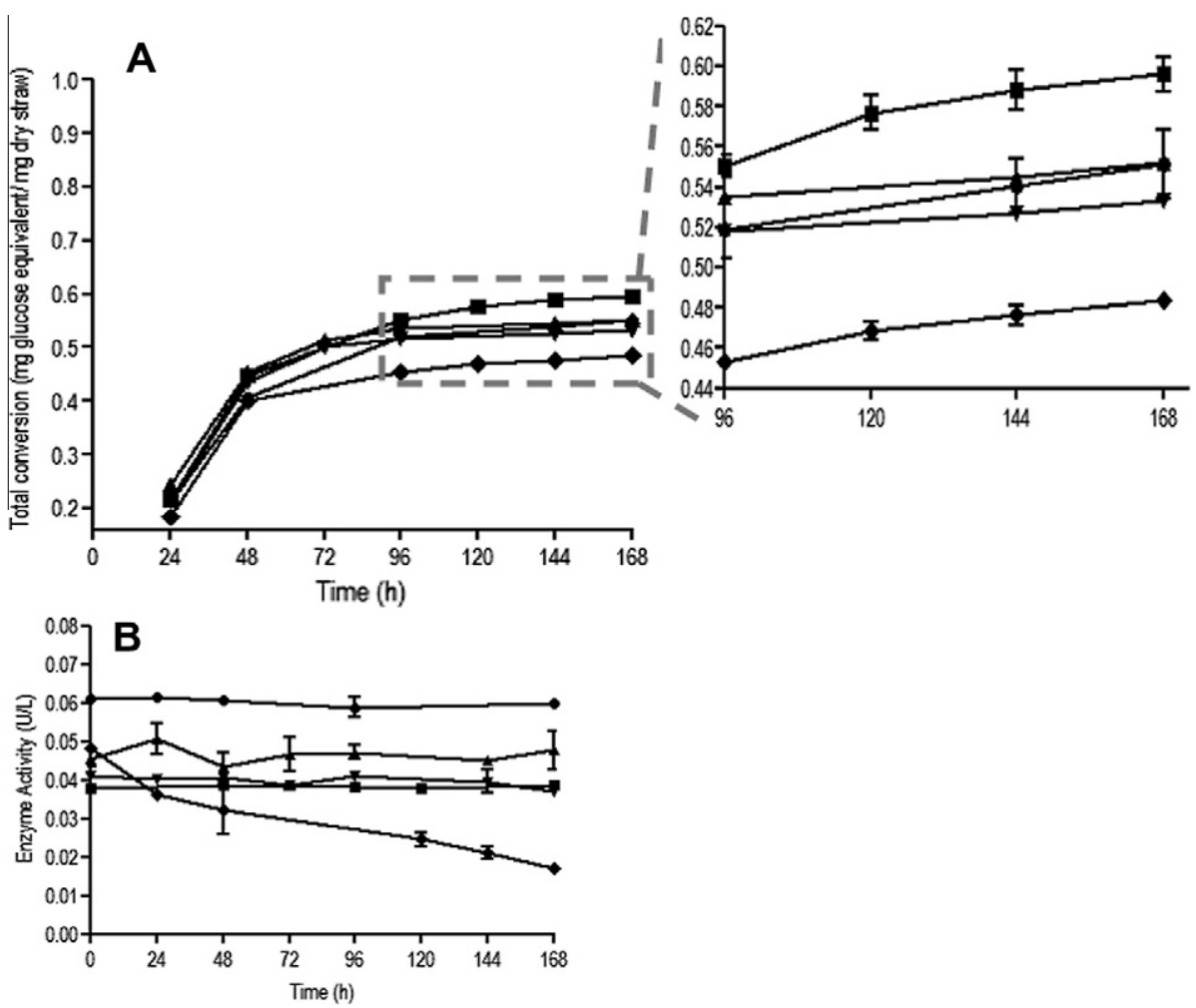

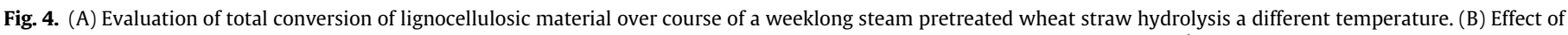

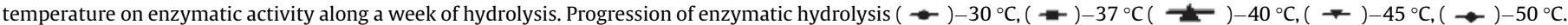
Data are expressed as the mean \pm SD (error bars) of two independent experiments performed in duplicate.

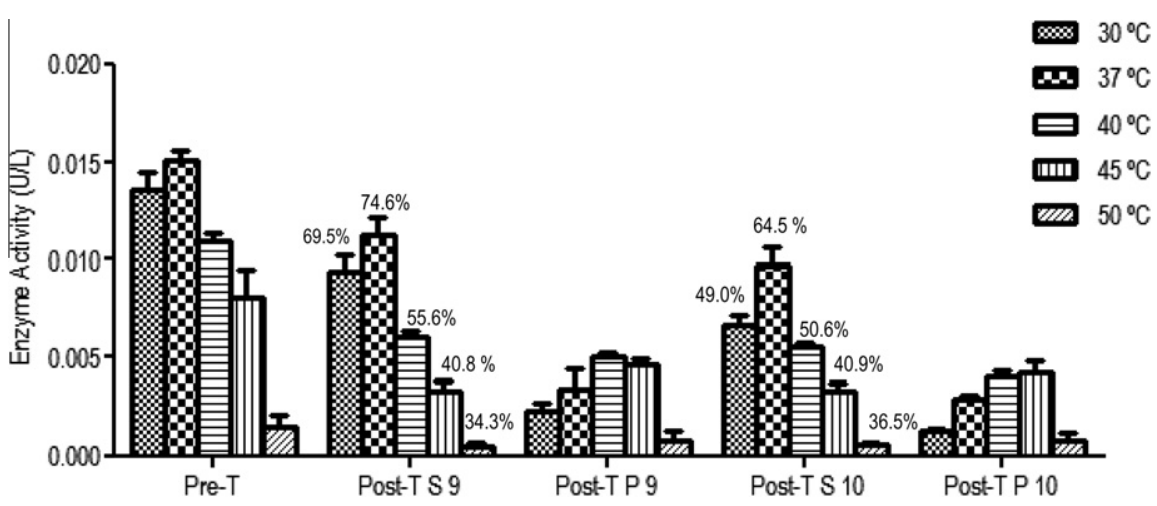

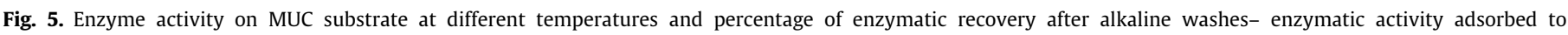

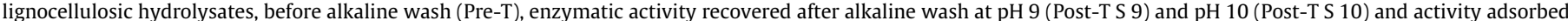

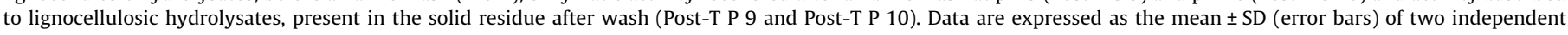
experiments performed in duplicate.

$45^{\circ} \mathrm{C}$, after incubation for $168 \mathrm{~h}$ (Fig. 4B). According to Ma et al. (2008), denatured protein binds the substrate irreversibly, thus occupying part of the surface, which limits the access of other functional proteins and thus decreases the rate of hydrolysis of the substrate. Indeed, as observed in Fig 4A, the higher the temperature - in the range of values used - the lower the conversion.

The straw residue obtained after the $168 \mathrm{~h}$ digestions was processed by alkaline wash, to estimate the amount of enzyme that may be recovered after a long period of incubation with the lignocellulosic substrate.

The results show that a higher MUC activity was detected in solid residue obtained using the lower temperature during the hydrolysis stage (Fig. 5, columns Pre-T). Cellulose conversion ap-
Table 1

Activity on filter paper fibers ${ }^{\mathrm{a}}$ - activity in the pellet before alkaline wash at different $\mathrm{pH}$ at the end of a weeklong hydrolysis (Pre-T) and total recovered enzymatic activity after alkaline wash at pH 9 (Post-T 9) and pH 10 (Post-T 10).

\begin{tabular}{llll}
\hline & Pre-T & Post-T 9 & Post-T 10 \\
\hline $30^{\circ} \mathrm{C}$ & $1.09 \pm 0.03$ & $1.93 \pm 0.01$ & $1.78 \pm 0.04$ \\
$37^{\circ} \mathrm{C}$ & $1.40 \pm 0.10$ & $2.57 \pm 0.07$ & $2.28 \pm 0.07$ \\
$40^{\circ} \mathrm{C}$ & $1.02 \pm 0.01$ & $1.72 \pm 0.1$ & $1.79 \pm 0.07$ \\
$45^{\circ} \mathrm{C}$ & $0.47 \pm 0.00$ & $1.23 \pm 0.05$ & $1.24 \pm 0.05$ \\
$50^{\circ} \mathrm{C}$ & $0.00 \pm 0.00$ & $0.68 \pm 0.03$ & $0.67 \pm 0.01$ \\
\hline
\end{tabular}

a The results of this assay are presented as the concentration of sugars hydrolyzed after $1 \mathrm{~h}$ incubation and are expressed in $\mathrm{mg} / \mathrm{ml} \pm \mathrm{SD}$ of total reducing sugars, glucose as standard. Data are expressed as the mean \pm SD (error bars) of two independent experiments performed in duplicate. 


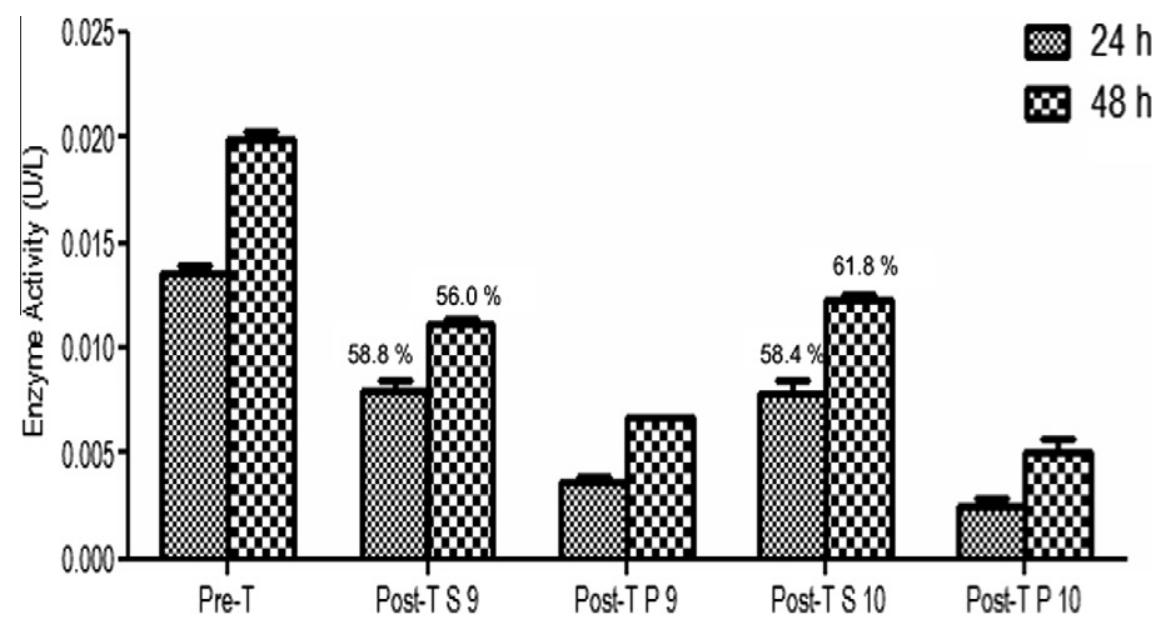

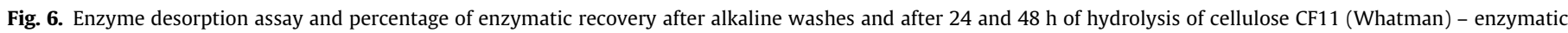

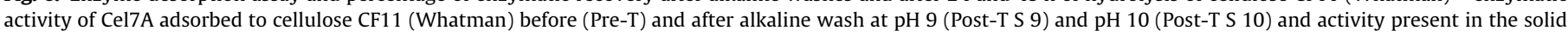
residue after wash (Post-T P 9 and Post-T P 10). Data are expressed as the mean \pm SD (error bars) of two independent experiments performed in duplicate.

pears to be related to the amount of active enzyme adsorbed on the solid fraction obtained after $168 \mathrm{~h}$ of hydrolysis, in accordance to the findings of Medve et al. (1998) and Karlsson et al. (1999). Probably due to denaturation, lower amounts of active enzyme were found in the straw residues obtained using higher temperature (Fig. 5, columns Pre-T).

Both pH 9 and 10 allowed for substantial desorption of the enzymes from the solid residue. Interestingly, there is a clear reduction of the recoverable active enzyme as the reaction temperature increased (Fig. 5, columns Post-T S 9 and Post-T S 10) despite the low enzyme activity remaining in the solid fraction.

Additionally, the enzyme activity of the recovered enzyme was also characterized using the filter paper fibres assay which, in contrast to the MUC assay, allows evaluation of the complete performance of the enzymes such as ability to adsorb, presence of synergistic endo- and exo- like activities, and others. When the solid residual fraction was mixed with filter paper, (without previous alkaline treatment) the adsorbed enzyme showed the ability to hydrolyze filter paper (Table 1, column Pre-T). Therefore the enzyme is able to desorb from one substrate onto another (Lee et al., 1995; Kumar and Wyman, 2009). This result was not found when the experiment was carried out at $50^{\circ} \mathrm{C}$, because the enzyme activity in the solid fraction was already very low. It should be noted that both alkaline treatments, for $2 \mathrm{~h}$, allowed recovery of activity in the filter paper fibers assay. The results confirmed that a higher straw hydrolysis obtained at lower temperature allows for increased enzyme recovery after alkali treatment of the residue (Table 1, columns Post-T 9 and 10). However, the activity of Celluclast on filter paper was preserved to some extent, and further work will be necessary to quantify the FPase activity of the recovered enzyme. When comparing $\mathrm{pH} 9$ with $\mathrm{pH} 10$ there are no significant differences $(p>0.05)$, which is consistent with the fact that recovery rates of enzyme were similar.

These results demonstrate that it is possible to recover a significant portion of adsorbed enzyme from complex heterogeneous substrates by a simple alkaline wash. However, contrarily to what was found using purified lignin, in the case of pre-treated straw, after alkaline treatment, some enzyme still remained adsorbed on the residue (Fig. 5, columns Post-T P 9 and 10). A solubilization of up to $66 \%$ of total straw dry mass was achieved at $37^{\circ} \mathrm{C}$. Although most cellulose should have been hydrolyzed, it is possible that a small portion still remained in the solid residue, in higher amount in the assays carried out at higher temperatures, since the conversion yield was lower in those cases. We speculate that the more effective the digestion, the more effective the enzyme recovery, using this methodology.

In order to clarify whether cellulose could interfere on the enzymatic desorption, we performed a desorption assay using pure cellulose CF11 (Whatman). The results show that, contrary to what was observed with pure lignin, although recovering more than 50\% (Fig. 6, columns Post-T S 9 and 10), the final pellet still contained a substantial amount of enzyme (Fig. 6, columns Post-T P 9 and 10). In this case the alkaline treatment was performed after only 24 and $48 \mathrm{~h}$ of incubation, because, as opposed to the case where lignin is used, the substrate is being hydrolyzed. However, the assay clearly demonstrates that alkaline treatment is more efficient in removing the enzymes from lignin than from cellulose.

With these results we demonstrate that optimizing the hydrolysis (careful selection of temperature is necessary) of the lignocellulosic substrate will directly impact the amount of recovered enzyme. By achieving higher hydrolysis the presence of cellulose in the final residue will be reduced, and subsequently recovery will be ameliorated.

\section{Conclusion}

Cel7A adsorbed on lignin retains 4-methylumbelliferyl- $\beta$-Dcellobioside activity. In the range of temperatures $\left(37-50{ }^{\circ} \mathrm{C}\right.$ ), an inverse relation between hydrolysis and temperature, corresponding to a correlation between the conversion yield and the recoverability of the active enzyme, was verified. We hypothesize that better recovery of the enzyme in alkaline $\mathrm{pH}$ depends on better cellulose hydrolysis since it was harder to wash the enzymes off cellulose than it is from lignin. The present work, confirms that the substantial amount of enzyme can be recovered from lignin and straw hydrolysates using a simple alkaline wash. Furthermore we show using low molecular mass fluorogenic specific substrates for determining the activities of desorbed cellulases that a modest $\mathrm{pH}$ switch does not lead to loss of catalytic activity of Cel7A, opening very good prospects towards enzyme recycling at an industrial scale.

\section{Acknowledgements}

The authors acknowledge funding through FP7 KACELLE (Kalundborg Cellulosic Ethanol) project for supporting his work. We 
also thank Dr. Mai Østergaard Haven for critical reviewing of the manuscript and Dr. Jane Lindedam for supplying the lignin.

\section{References}

Adney, B., Baker, J., 1996. Measurement of Cellulase Activities Laboratory Analytical Procedure, NREL LAP-006.

Bajaj, B., Pangotra, H., Wani, M., Sharma, P., Sharma, A., 2009. Partial purification and characterization of highly thermostable and $\mathrm{pH}$ stable endoglucanase from a newly isolated Bacillus strain M-9. Indian J. Chem. Technol. 16, 287-382.

Deshpande, M.V., Eriksson, K.E., 1984. Reutilization of enzymes for saccharification of lignocellulosic materials. Enzyme Microb. Technol. 6 (8), 338-340.

Eriksson, T., Borjesson, J., Tjerneld, F., 2002. Mechanism of surfactant effect in enzymatic hydrolysis of lignocelluloses. Enzyme Microb. Technol. 31, 353-364.

Fasching, M., Schröder, P., Wollboldt, R.P., Weber, H.K., Sixta, H., 2008. A new and facile method for isolation of lignin from wood based on complete wood dissolution. Holzforschung 62, 15-23.

Karlsson, J., Medve, J., Tjerneld, F., 1999. Hydrolysis of steam-pretreated lignocellulose. Synergism and adsorption for cellobiohydrolase I and endoglucanase II of Trichoderma reesei. Appl. Biochem. Biotechnol. 82, 243-258.

Kumar, R., Wyman, C., 2009. Access of cellulase to cellulose and lignin poplar solids produced by leading pretreatment technologies. Biotechnol. Prog. 25, 807-819.

Laresen, J., Petersen, M.Ø., Thirup, L., Li, H.W., Iversen, F.K., 2008. The IBUS process lignocellulosic bioethanol close to a commercial reality. Chem. Eng. Technol. 31, 765-772.

Lee, D., Yu, A.H.C., Saddler, J.N., 1995. Evaluation of cellulase recycling strategies for the hydrolysis of lignocellulosic substrates. Biotechnol. Bioeng. 45, 328-336.

Li, J., Jiang, Z., Wu, H., Long, L., Jiang, Y., Zhang, L., 2008. Improving the recycling and storage stability of enzyme by encapsulation in mesoporous $\mathrm{CaCO}_{3}$-alginate composite gel. Compos. Sci. Technol 69, 539-544.

Lu, Y.P., Yang, B., Gregg, D., Saddler, J.N., Mansfield, S.D., 2002. Cellulase adsorption and an evaluation of enzyme recycle during hydrolysis of steam-exploded softwood residues. Appl. Biochem. Biotech. 98, 641-654.

Ma, A., Hu, Q., Qu, Y., Bai, Z., Liu, W., Zuang, G., 2008. The enzymatic hydrolysis rate of cellulose decreases with irreversible adsorption of cellobiohydrolase I. Enzyme Microb. Tech. 42, 543-547.

Medve, J., Karlsson, J., Lee, D., Tjerneld, F., 1998. Hydrolysis of microcrystalline cellulose by cellobiohydrolase I and endoglucanase II from Trichoderma reesei: adsorption, sugar production pattern, and synergism of the enzymes. Biotechnol. Bioeng. 59, 621-634.

Otter, D.E., Munro, P.A., Geddes, R., 1984. Elution of Trichoderma reesei cellulase from cellulose by $\mathrm{pH}$ adjustment with sodium hydroxide. Biotechnol. Lett. 6, 369-374.
Palonen, H., Tenkanen, M., Linder, M., 1999. Dynamic interaction of Trichoderma reesei cellobiohydrolases Cel6A and Cel7A and cellulose at equilibrium and during hydrolysis. Appl. Environ. Microbiol. 65, 5229-5233.

Palonen, H., Tjerneld, F., Zacchi, G., Tenkanen, M., 2004. Adsorption of Trichoderma reesei $\mathrm{CBH}$ I and EG II and their catalytic domains on steam pretreated softwood and isolated lignin. J. Biotechnol. 107, 65-72.

Petersen, M.O., Larsen, J., Thomsen, M.H., 2009. Optimization of hydrothermal pretreatment of wheat straw for production of bioethanol at low water consumption without addition of chemicals. Biomass Bioenerg. 33, 834-840.

Qi, B., Chen, X., Su, Y., Wan, Y., 2011. Enzyme adsorption and recycling during hydrolysis of wheat straw lignocelluloses. Bioresour. Technol. 102 (3), 28812889.

Ramos, L.P., Breuil, C., Saddler, J.N., 1992. Comparison of steam pretreatment of Eucalyptus, Aspen, and spruce wood chips and their enzymatic hydrolysis. Appl. Biochem. Biotechnol. 34 (35), 37-47.

Rollin, J., Zhu, Z., Sathitsuksanoh, N., Zhang, Y.-H., 2011. Increasing cellulose accessibility is more important then removing lignin: a comparison of cellulose solvent-based lignocelluloses fractionation and soaking in aqueous ammonia. Biotechnol. Bioeng. 108, 22-30.

Rosgaard, L., Pedersen, S., Langston, J., Akerhielm, D., Cherry, J.R., Meyer, A., 2007. Evaluation of minimal Trichoderma reesei cellulose mixtures on differently pretreated barley straw substrates. Biotechnol. Prog. 23, 1270-1276.

Schevechenko, S.M., Chang, K., Dick, D.G., Gregg, D.J., Saddler, J.N., 2001. Structure and properties of lignin in softwoods after $\mathrm{SO}_{2}$-catalyzed steam explosion and enzymatic hydrolysis. Cellul. Chem. Technol. 35, 487-502.

Tan, S.S.Y., MacFarlane, D.R., Upfal, J., Edye, L.A., Doherty, W.O.S., Patti, A.F., Pringle, A.F., Scott, J.L., 2009. Extraction of lignin from lignocelluloses at atmospheric pressure using alkylbenzenesulfonate ionic liquid. Green Chem. 11, 339-345.

Tu, M., Chandra, R.P., Saddler, J.N., 2007a. Evaluating the distribution of cellulases and the recycling of free cellulases during the hydrolysis of lignocellulosic substrates. Biotechnol. Prog. 23, 398-406.

Tu, M., Chandra, R.P., Saddler, J.N., 2007b. Recycling cellulases during the hydrolysis of steam exploded and ethanol pretreated lodgepole pine. Biotechnol. Prog. 23. 1130-1137.

Wingren, A., Galbe, M., Zacchi, G., 2003. Techno-economic evaluation of producing ethanol from softwood: comparison of SSF and SHF and identification of bottlenecks. Biotechnol. Prog. 19, 1109-1117.

Yang, B., Wayman, C.E., 2006. BSA treatment to enhance enzymatic hydrolysis of cellulose in lignin containing substrates. Biotechnol. Bioeng. 94, 611-617.

Zhao, X., Cheng, K., Liu, D., 2009. Organosolv pretreatment of lignocellulosic biomass for enzymatic hydrolysis. Appl. Microbiol. Biotechnol. 82 (5), 815-827.

Zhu, Z., Sathitsuksanoh, N., Zhang, Y.-H.P., 2009. Direct quantitative determination of adsorbed cellulase on lignocellulosic biomass with its application to study cellulase desorption for potential recycling. Analyst 134, 2267-2272. 